\title{
Morphologic variation in the P1 element of Mississippian species of the conodont genus Pseudognathodus
}

\author{
Javier SANZ-LÓPEZ ${ }^{1 *}$, Silvia BLANCO-FERRERA ${ }^{1} \&$ C. Giles MILLER ${ }^{2}$
}

${ }^{1}$ Departamento de Geología, Facultad de Geología, Universidad de Oviedo, c/ Jesús Arias de Velasco s/n, 33005 Oviedo, Spain; sanzjavier@uniovi.es; blancosilvia@uniovi.es

${ }^{2}$ Department of Earth Science, Natural History Museum, Cromwell Road, London SW7 5BD, UK; G.Miller@nhm.ac.uk

* Corresponding author

Sanz-López, J., Blanco-Ferrera, S. \& Miller, C.G. 2018. Morphologic variation in the P1 element of Mississippian species of the conodont genus Pseudognathodus. [Variación en la morfología de los elementos P1 en las especies de conodontos del Misisípico del género Pseudognathodus]. Spanish Journal of Palaeontology, 33 (1), 185-204.

\section{ABSTRACT}

A revision of the Austin Conodont Collection at the Natural History Museum, London, has revealed a diverse assemblage of P1 elements of Pseudognathodus. Pseudognathodus homopunctatus, Ps. lineatus, Ps. mermaidus and Ps. symmutatus are differentiated and a new species, Ps. posadachaconae, is defined from material from North Wales. The systematic of these species is updated. A revised diagnosis is provided for the genus Pseudognathodus, as well as for the species Ps. lineatus and Ps. symmutatus. The types of Ps. symmutatus cannot be differentiated from immature specimens of Ps. homopunctatus. The evolutionary relationships of Pseudognathodus species are discussed. Stratigraphic distribution indicates that diversity increased moderately from the upper Tournaisian and lower Viséan to the upper Viséan (Mississippian, Carboniferous). Pseudognathodus homopunctatus and Ps. symmutatus are widely distributed palaeogeographically whereas $P$ s. lineatus and Ps. posadachaconae sp. nov. are endemic.

Keywords: Conodont, Pseudognathodus, systematics, Mississippian, Viséan.

\section{RESUMEN}

Una revisión de los conodontos de la Colección Austin del Museo de Historia Natural en Londres ha puesto de manifiesto la diversidad de los elementos P1 de Pseudognathodus. Además de las especies Ps. homopunctatus, Ps. lineatus, Ps. mermaidus y Ps. symmutatus, una especie nueva, Ps. posadachaconae, es propuesta para ejemplares del Norte de Gales. La sistemática de todas las especies del género es revisada e incluye una diagnosis para el género Pseudognathodus y para las especies Ps. lineatus and Ps. symmutatus. Los tipos de Ps. symmutatus no pueden ser distinguidos de los ejemplares inmaduros de $P s$. homopunctatus. Se discuten las relaciones evolutivas entre las distintas especies de Pseudognathodus. La distribución estratigráfica de las mismas indica un incremento moderado en la diversidad del género desde el Tournaisiense superior y el Viseense inferior al Viseense superior (Misisípico, Carbonífero). Pseudognathodus homopunctatus y Ps. symmutatus tuvieron una distribución paleogeográfica extensa, mientras que Ps. lineatus y Ps. posadachaconae sp. nov. fueron especies endémicas.

Palabras clave: Conodonto, Pseudognathodus, sistemática, Misisípico, Viseense. 


\section{INTRODUCTION}

Gnathodus commutatus homopunctatus Ziegler has been used to identify the base of the Viséan, Mississippian (Devuyst et al., 2003). P1 elements of this taxon are morphologically similar to Gnathodus symmutatus Rhodes et al., and G. symmutatus mermaidus Austin \& Husri, although their identification has been subject to much discussion. Metcalfe (1980) included the three taxa in G. homopunctatus based on their similarity and coeval presence along similar stratigraphic ranges. Austin \& Husri (1975) considered them to be three subspecies of G. symmutatus, whereas many authors recognise three valid species assigned by Stone (1991) to the so-called homopunctatus group. The original designation of this group to the genus Gnathodus Pander was also questioned with Stone (1991) naming it informally Gnathodus sensu lato. Park (1983) had previously included these species in the genus Pseudognathodus nomen nudum. Dzik (1997) included them in Protognathodus Ziegler, based on the similarity of the P1 element, whereas Barskov et al. (1987), and Tian \& Coen (2005), among others, preferred to assign them to Paragnathodus Higgins, a junior synonym of Lochriea Scott. Atakul-Özdemir et al. (2012) following cladistic analysis, considered $G$. homopunctatus to belong to Lochriea based on the co-occurrence of discrete elements of the apparatus of Lochriea with mature P1 elements of $G$. homopunctatus in three samples from Lancashire (United Kingdom).

In our opinion, the G. homopunctatus group (sensu Stone, 1991) additionally comprises specimens from the Viséan of Ireland differentiated by Austin \& Husri (1975) as $G$. commutatus lineatus sp. nov. and G. commutatus multinodosus Higgins, nomen nudum, which currently belongs to Lochriea multinodosa (Wirth). Ronald Austin's Collection housed in the Natural History Museum, London (NHMUK), includes the type specimens of G. symmutatus, G. symmutatus mermaidus, and G. commutatus lineatus, as well as many specimens in assemblage slides showing the morphologic variation of the P1 element in the $G$. homopunctatus group. The aims of this work are to review this morphologic variation and to update the systematic of this species group. We conclude that they belong to the genus Pseudognathodus Perret. We have focused on the morphology of the P1 element, as there seems to be sufficient variation to differentiate the genus, although the validity of the species in this genus should be supported by more data about the other elements forming the apparatus.

\section{MATERIALS AND METHODS}

This study concentrated on the type and figured material in Ronald Austin's Collection housed in the NHMUK but also included specimens picked from assemblage slides deposited later in 1993. Rhodes et al. (1969) studied Pseudognathodus symmutatus from samples CYD 7 to 3D 14/15 at Craig-y-Dinas and Melte Bridge in the North Crop of the Coalfield of the South Wales. The taxon was associated with Pseudognathodus homopunctatus, Lochriea mononodosa (Rhodes et al.), and Gnathodus girty collinsoni Rhodes et al. in upper Brigantian beds (upper Viséan to lower Serpukhovian, Mississippian) according to Higgins (1985, table 6). In these samples, specimens of Ps. symmutatus (42 elements) are smaller than those of Ps. homopunctatus (146 elements).

Elements assigned to Ps. homopunctatus and Ps. symmutatus were studied by Aldridge et al. (1968) in Flintshire (North Wales; 56 elements). Samples were collected from the Moel Hiraddug Limestone to the Prestatyn Limestone (Regional upper Arundian to upper Asbian substages, Viséan) according to Somerville et al. (1986). The abundance of conodonts in these samples is relatively low.

Austin \& Husri (1975) described a wide variation from sections in counties Limerick and Clare (Republic of Ireland), where they differentiated Ps. homopunctatus (544 elements), Ps. symmutatus (406 elements), and, of particular interest to this study, Ps. mermaidus (84 elements), G. c. lineatus (56 specimens), and G. c. multinodosus (15 elements). Samples from County Limerick were collected from the Rathkeale and Corgrig Lodge formations that are upper Chadian to Brigantian (Viséan). Samples from County Clare (west of the River Fergus and islands in the estuary of the Shannon) correspond to similar stratigraphic interval as the Limerick area, between the Mermaid and the Inishtubrid Beds (Austin \& Husri, 1975).

It is difficult to investigate the species concepts of Austin \& Husri (1975) from their assemblage slides as many of the specimens, apart from the figured specimens, are loose. Slide labels include abbreviated notations in pencil (eg. "G. homo", "G. merma", "G. line", "G. multi") that seem to correspond to the previous determinations by Austin \& Husri (1975). Another difficulty is the occurrence of secondary apatite and calcite overgrowths on many of the specimens (irregular envelope microtexture after BlancoFerrera et al., 2011). This envelope may mask or modify the observation of ornamentation of the cup. The overgrowth and original relief of the cup can only be seen by magnification and observation under a scanning electronic microscope (SEM). Specimens were selected for observation and illustration in the Core Research Laboratories (Imaging and Analysis Centre) of the NHMUK using a Hitachi S-2500 scanning electron microscope. Unfortunately, one of the aluminum stubs was damaged during the Aucoating process, prior to SEM study. All of the specimens on the stub were lost including the paratype (NHMUK PM X 1754) and the holotype (NHMUK PM X 1755) of G. symmutatus mermaidus (Austin \& Husri, 1975, pl. 2, fig. 11 and pl. 4, fig. 10, respectively) and the holotype 
(NHMUK PM X 1723) and paratype (NHMUK PM X 1724) of G. commutatus lineatus (Austin \& Husri, 1975, pl. 2, fig. 9 and pl. 4, fig. 11). Other characteristic specimens were chosen and have been illustrated as part of this study.

Pseudognathodus homopunctatus is very abundant in a bed of nodular cephalopod-bearing limestone of the Mississippian Alba Formation at the Portillas del río Nevandi (Cantabrian Mountains, Spain). A few elements have been used to illustrate ornamentation changes during ontogeny. Illustrated conodonts from this sample are housed in the Department of Geology Museum of the University of Oviedo (abbreviated prefix DGO in the catalogue number). The rest of the illustrated material is housed at the Natural History Museum in London (NHMUK). The notation and orientation applied in the conodont descriptions follow Purnell et al. (2000).

\section{SYSTEMATICS}

\section{Order OZARKODINIDA Dzik, 1976}

Family Gnathodontidae Sweet, 1988

Genus Pseudognathodus Perret, 1993

Type species Gnathodus homopunctatus Ziegler, 1960, by original designation.

Diagnosis. Modified from Park (1983). P1 element with a distal outline of the cup from ellipsoidal to sub-triangular; the widest part at the ventral cup. Ornamentation may be lacking on a low cup that may show a swollen area close to the carina in the proximal cup, or a terrace with a stepped margin surrounded by a veil (term for the marginal flared area after Purnell \& von Bitter, 1992). Ornamentation varies from a few nodes, to a row of nodes or transverse ridges on each side of the cup, or to a group of nodes. The dorsal (adaxial) outline shows a curved outline. The highest denticles are in the central part of the ventral blade, but not at the ventral margin. In some species, the highest denticles are in the dorsal part of the blade.

Remarks. Park (1983) included Gnathodus commutatus homopunctatus Ziegler and Gnathodus symmutatus Rhodes et al., in a new genus, Pseudognathodus, characterised by the lack of a caudal parapet and a semi-elliptical oral outline. The proposal did not satisfy the requirements of publication specified by the International Commission on Zoological Nomenclature (1999, Article 9.12). Nevertheless, Perret (1993) described and adopted the genus Pseudognathodus Park including Ps. homopunctatus and Ps. symmutatus and was followed by other authors (Perret et al., 1994; Skompski, 1996; Perri \& Spalleta, 1998; Meischner \& Nemyrovska, 1999; Kullmann et al., 2008; see synonymy list of Ps. homopunctatus). Only Park (1983) included diagnosis for the genus. On basis of the differences of $\mathrm{P} 1$ elements with respect to other genera, we have cautiously assumed the validity of the genus Pseudognathodus for the present study, but suggest that more data is needed about the other elements forming the apparatus to confirm this.

Protognathodus Ziegler is homeomorphic with Pseudognathodus. Both show a subsymmetrical or symmetrical cup with an ellipsoidal outline of the cup and ornamentation lacking, few nodes or rows of nodes in each half of the cup (Fig. 1d). The descendant species of Protognathodus, Gnathodus Pander has a distinct asymmetrical cup with the narrow caudal half variably ornamented. The oral or adaxial outline of the blade-carina in Protognathodus and Gnathodus shows a high blade to the ventral end with the highest denticles. The outline of denticles on the blade-carina forms a continuous curve that dorsally decreases in height, (Figs 1e, 1h-1i). At the ventral end of the blade, lower denticles and a shorter blade is observed, particularly in small specimens, and in several species (Fig. 1h). The dorsal outline of Pseudognathodus decreases in height towards the dorsal and ventral ends according to Park (1983) and Perret (1993) (Figs 1a-1c). There may be one or several lower denticles on the ventral blade (Figs 1a-1c) but the decreasing height of the ventral blade is a useful character to differentiate Pseudognathodus. However, this characteristic may be less marked in large specimens of Pseudognathodus where high denticles are very close at the ventral end of the free blade (see Figure $2 \mathrm{f}$ in Atakul-Özdemir et al., 2012). Furthermore, the denticles may be fused as a ridge in the proximal area (just above the basal cavity) in specimens of both genera (Figs 1b-1c, 1h-1i). Stone (1991) used Gnathodus sensu lato because of the similarity to gnathodontids.

Species of Lochriea Scott show a high ventral blade, with the highest denticles normally close to the ventral margin (Figs $1 \mathrm{j}-1 \mathrm{~m}$ ). The dorsal outline may decrease in height in immature specimens or oldest species of the genus (Lochriea saharae Nemyrovska et al.), but the dorsal termination is high with a straight margin in other species and in mature elements. Furthermore, P1 elements of Lochriea have a lower number of denticles, which that are triangular in outline and only isolated at the tips (Fig. 1j). The cup is wide on either side of the blade, increasing in width with the development of ornamentation concentrated in the transverse, swollen, proximal areas with a transverse disposition. The expansion of the cup is mostly along the rostral-caudal axis and characteristically asymmetric in ornamented species. The rostral side is more expanded than the caudal. The caudal margin is only slightly expanded close to the dorsal margin and forms a curved sinus from the second or third denticle of the carina. AtakulÖzdemir et al. (2012) considered G. homopunctatus to be within Lochriea, based on a cladistic analysis of cooccurring discrete elements of the apparatus and mature 


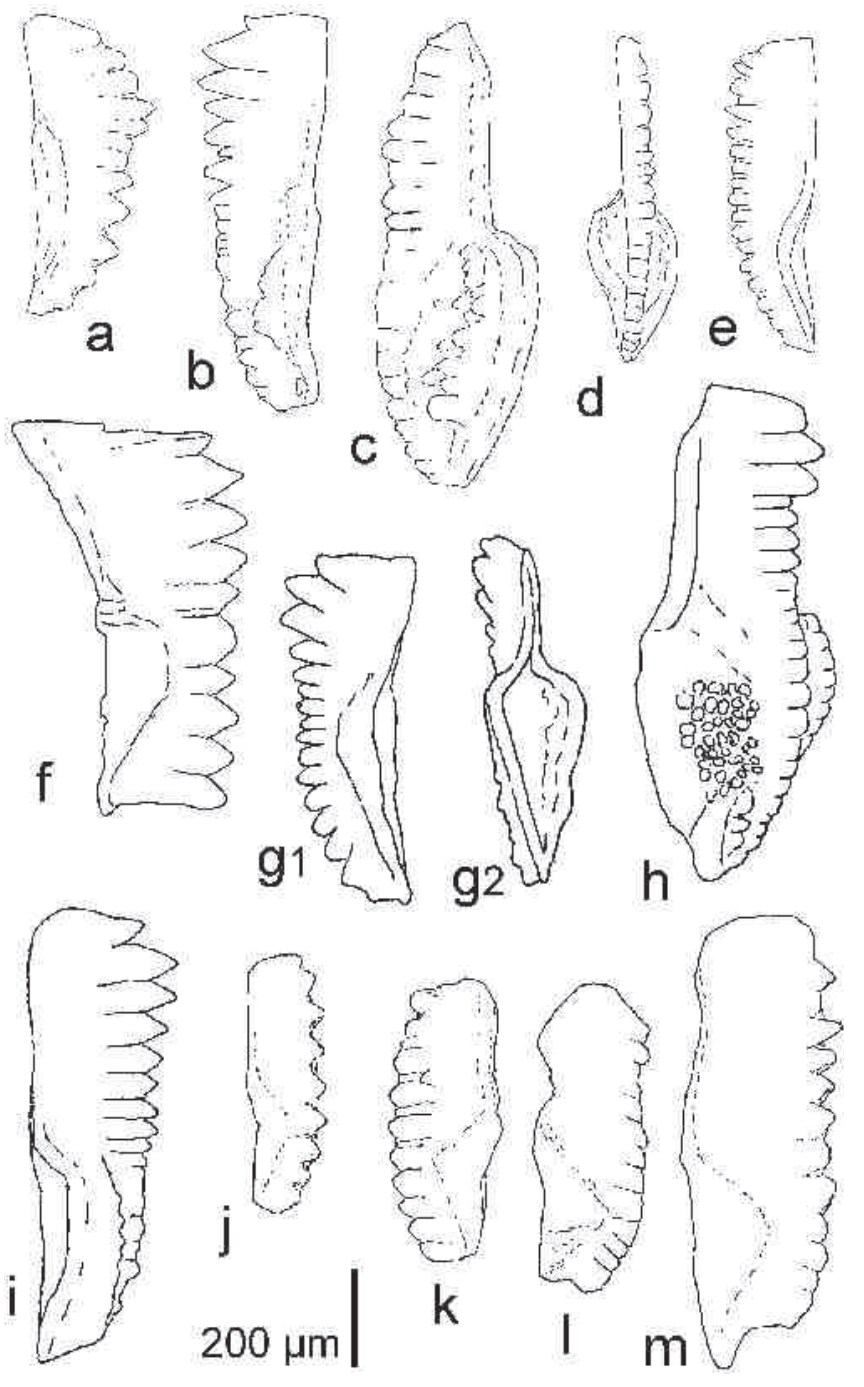

Figure 1. Outline drawings from various publications of P1 elements in lateral views. a) Pseudognathodus symmutatus (Rhodes et al.), NHM PM X 1750, sample L. 7 after Austin \& Husri (1975, pl. 4, fig. 7a). b) Pseudognathodus homopunctatus (Ziegler), NHMUK PM X1752, sample L. 7 after Austin \& Husri (1975, pl. 4, fig. 9c). c) Pseudognathodus lineatus (Austin \& Husri), NHMUK PM X 1725, sample Cl. 12B from Austin \& Husri (1975, pl. 2, fig. 13). d) Protognathodus cf. collinsoni Ziegler, SLU 406 after Chauffe \& Nichols (1995, pl. 2, fig. 32). e) Protognathodus meischneri Ziegler, SLU 403 after Chauffe \& Nichols (1995, pl. 2, fig. 33). f-g2) Cudotaxis pricesilingi Chauff, holotype SUI 45239 and paratype SUI 45238 after Chauff (1981, pl. 3, figs 25, 26 and 30). h) Gnathodus bilineatus (Roundy), NHMUK PM X 1717, sample D after Austin \& Husri (1975, pl. 3, fig. 7c). 16. i) Gnathodus girtyi Hass, NHMUK PM X 1738, sample B. 14 after Austin \& Husri (1975, pl. 3, fig. 3b). j-l) Lochriea commutata (Branson \& Mehl), NHMUK PM X 1719- NHMUK PM X 1721, sample L. 10 the first and L. 7 for the others after Austin \& Husri (1975, pl. 2, figs 1c, 2c and 3c). m) Lochriea scotiaensis (Globensky), NHMUK PM X1722, sample Cl. 12B after Austin \& Husri (1975, pl. 2, fig. 12c).
P1 elements in three samples from Lancashire. Elements of the apparatus of Lochriea occur without P1 elements of Lochriea but with P1 of G. homopunctatus (AtakulÖzdemir et al., 2012). However, this hypothesis is based on a small number of elements per sample (11 P1 of PS. homopunctatus / 2 P2, $3 \mathrm{M}$ and $5 \mathrm{~S}$ of Lochriea in sample BSG 20680; 6 P1 / 1 M in BSG 20684; 12 P1 / $2 \mathrm{M}$ in BSG 26086 according to their table 1). Atakul-Özdemir et al. (2012) studied samples from the English Arundian (early Viséan), and other British Arundian sections yielded P1 elements of Lochriea commutata and L. saharae (Stone, 1991). Consequently, the apparatus structure of Ps. homopunctatus needs be confirmed.

Cudotaxis Chauff is a Tournaisian genus from North America (Chauff, 1981, pl. 3, figs 25-26, 30-32) that shows an expanded and wide dorsal cup (Figs 1f-1g2), although it could be a morphologic convergence with Pseudognathodus. Immature elements of Cudotaxis priceslingi Chauff show a convex outline of the denticle tips similar to Pseudognathodus (Fig. 1g1). However, the denticulation is more irregular than in Pseudognathodus, with lower and smaller denticles in the middle of the element. Strong and deeply inserted denticles are present in strongly arched mature elements (Fig. 1f).

\section{Pseudognathodus homopunctatus (Ziegler, 1960)}

(Figs 1b, 2a1-2m, 4b)

1957 Gnathodus commutatus punctatus, Bischoff, p. 24, pl. 4, figs 7-11, 14.

*1960 Gnathodus commutatus homopunctatus, Ziegler, p. 5 , pl. 4, fig. 3 .

1961 Gnathodus commutatus Branson \& Mehl var. homopunctatus Bischoff, Higgins, pl. 10, fig. 9.

1962 Gnathodus commutatus homopunctatus, Ziegler, p. 395 , pl. 4 , fig. 3 .

1962 Gnathodus commutatus homopunctatus, Higgins, pl. 2, fig. 21.

? 1965 Gnathodus commutatus homopunctatus, Spassov, p. 159, pl. 3, fig. 13.

1967 Gnathodus commutatus homopunctatus, Wirth, p. 206, 207, pl. 19, fig. 12.

P 1967 Gnathodus commutatus homopunctatus, Spassov \& Filipović, p. 62, pl. 8, fig. 3 (only).

1969 Gnathodus commutatus homopunctatus, Spassov et al., p. 159, pl. 3, fig. 17.

1969 Gnathodus commutatus (Branson \& Mehl), Thompson \& Goebel, p. 23-24, pl. 4, figs 4, 6, 7.

v 1969 Gnathodus homopunctatus, Rhodes et al., p. 103, pl. 19, figs 5a-8d. 
1970 Gnathodus commutatus homopunctatus, Reynolds, p. 10 , pl. 1, fig. 8 .

1973 Gnathodus homopunctatus, Igo, p. 194, pl. 29, figs 18-21.

v 1973 Gnathodus homopunctatus, Austin \& Aldridge, pl. 1, fig. 2.

1974 Gnathodus sp., Mathews \& Thomas, pl. 51, figs 4, 8-9.

1974 Gnathodus commutatus homopunctatus, Mathews \& Thomas, pl. 51, fig. 6.

v 1975 Gnathodus symmutatus homopunctatus, Austin \& Husri, pl. 4, figs 1, 9, 12.

p v1975 Gnathodus symmutatus symmutatus Rhodes et al., Austin \& Husri, pl. 4, figs 6a-6b (only).

1975 Gnathodus homopunctatus, Higgins, p. 33-34, pl. 7, figs 1-6; pl. 10, fig. 7.

1976 Gnathodus symmutatus homopunctatus, Bless et al., pl. 14, figs 6, 8-10.

1976 Gnathodus cf. homopunctatus, Groessens in Conil et al., pl. 6, figs 14-15.

1977 Gnathodus cf. homopunctatus, Groessens \& Noël, pl. 1.

1977 Gnathodus homopunctatus, Groessens \& Noël, pl. 2, pl. 7, fig. 26.

1977 Gnathodus symmutatus homopunctatus, Perret, pl. 51, fig. 25.

1978 Gnathodus homopunctatus, Menéndez-Álvarez, pl. 1, fig. 6 .

p 1978 Gnathodus symmutatus, Kozitskaya et al., pl. 11, fig. 5 .

1978 Gnathodus homopunctatus, Kozitskaya et al., pl. 11, figs 6-7.

1979 Gnathodus commutatus homopunctatus, Buchroithner, pl. 1, fig. 3; pl. 2, fig. 1.

1980 Gnathodus homopunctatus, Metcalfe, pl. 13, fig. 17.

1980 Gnathodus homopunctatus, Tynan, pl. 1, figs 1-2. 1980 Paragnathodus commutatus, Tynan, pl. 1, figs 3-4. p 1981 Gnathodus homopunctatus, Metcalfe, p. 27, pl. 5, figs 1, 3-5 (only).

1982 Gnathodus homopunctatus, Higgins \& WagnerGentis, pl. 34, fig. 7.

1984 Gnathodus homopunctatus, Austin \& Davies, pl. 3 , figs 25,33 .
1984 Gnathodus homopunctatus, Chaplin, pl. 5, figs 5-7.

? 1984 Gnathodus nodosus Bischoff, Chaplin, pl. 6, fig. 1.

1985 Gnathodus homopunctatus, Varker \& Sevastopulo, p. 200, pl. 5.5, figs 14-15, 19, 21-22.

1985 Gnathodus homopunctatus, Belka, pl. 5, figs 6-14.

1985 Gnathodus mermaidus (Austin \& Husri), Belka, pl. 7 , fig. 9 .

1985 Gnathodus symmutatus $\rightarrow$ G. homopunctatus, Belka, pl. 15, fig. 8.

1985 Paragnathodus homopunctatus, Weyant, pl. 5, figs 8-9.

p 1986 Gnathodus symmutatus, Belka \& Groessens, pl. 7, fig. 7 (only).

1986 Gnathodus cf. homopunctatus, Belka \& Groessens, pl. 7, figs $8-10$.

1986 Gnathodus homopunctatus, Belka \& Groessens, pl. 7, figs 11-15.

1987 Gnathodus sp. cf. G. homopunctatus, Austin, pl. 13.1, figs 1-3, 12; pl. 13.2, figs 4-6, 15, 21-26; pl. 13.3, figs $4-6,8,10$.

p 1987 Paragnathodus (?) homopunctatus, Barskov et al., pl. 16, figs 3-5 (only).

1987 Gnathodus? homopunctatus, Orchard, pl. 78.1, fig. 8.

1991 Gnathodus sensu lato homopunctatus, Stone, p. 28-29, pl. 3, figs $1-4$.

p 1993 Pseudognathodus homopunctatus, Perret, p. 349, 351, figs 122A, C; pl. C5, figs 21-24, 26 (only).

1994 Pseudognathodus homopunctatus, Perret et al., pl. 3, fig. 14.

1996 Paragnathodus homopunctatus, Kozitskaya \& Nemirovskaya in Einor et al., pl. 8, fig. 20.

1996 Pseudognathodus homopunctatus, Skompski, pl 1, fig. 10; pl. 2, fig. 3.

1998 «Gnathodus» homopunctatus, Belka \& Lehmann, pl. 2, figs $7-8$.

p 1998 Pseudognathodus homopunctatus, Perri \& Spalletta, pl. 2, figs 6-7 (only).

1999 Pseudognathodus homopunctatus, Meischner \& Nemyrovska, pl. 4, figs 5, 7, 11, 23.

1999 Gnathodus homopunctatus, Somerville \& Somerville, pl. 1, fig. 11.

2003 Pseudognathodus homopunctatus, Groves et al., fig. $3.5 \mathrm{a}-\mathrm{c}$. 


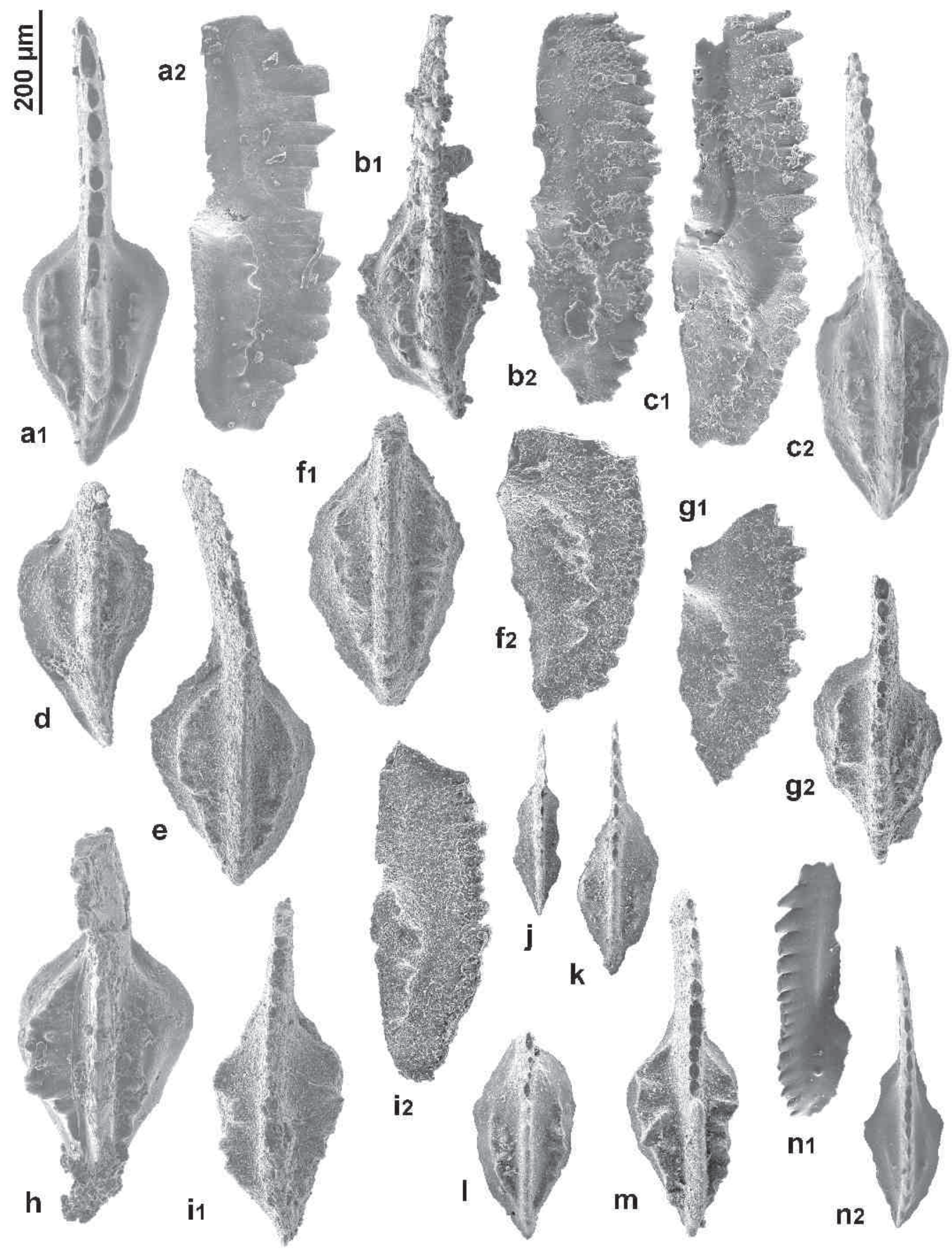


2004 Gnathodus homopunctatus, Bermúdez-Rochas et al., p. 49-50, 52, pl. 7, figs 1-6, 8-9, 11.

2004 Paragnathodus homopunctatus, Tian \& Coen, pl. 1, figs 17-19.

v 2005 Pseudognathodus homopunctatus, BlancoFerrera et al., pl. 6.31.

2005 Pseudognathodus homopunctatus, Nemyrovska, p. 45-46, pl. 7, figs 2-3.

2005 Pseudognathodus mermaidus (Austin \& Husri), Nemyrovska, p. 45-46, pl. 7, fig. 1.

2005 Pseudognathodus homopunctatus, Qi \& Wang, pl. 1, fig. 1 .

2006 Pseudognathodus homopunctatus, Nemyrovska et al., pl. 4, figs 1-5, 7.

2006 Gnathodus homopunctatus?, Dumoulin et al., pl. 2, fig. 13.

2009 Paragnathodus homopunctatus, Nikolaeva et al., pl. 3.10.

2010 Pseudognathodus homopunctatus, Pazukhin et al., pl. 3, fig. 10.

2010 Paragnathodus homopunctatus, Nigmadhaznov et al., pl. 2, figs 4-5.

2014 Pseudognathodus homopunctatus, Gatovskii \& Zhorina, figs 6-10.

2014 Pseudognathodus homopunctatus, Qi et al., fig. $4 \mathrm{~m}$.

2016 Pseudognathodus homopunctatus, Kabanov et al., fig. 12B.

Synonymy lists are annotated using the symbols recommended by Matthews (1973). Records preceded by $(*)$ provide the original definition and illustration of material type and diagnosis of the species; (?) indicates doubt that the published material is within the species; (v) vide marks that the authors have seen the specimen/s; (p) pars notes that only part of the specimens in the reference belong to the species; (non) shows distinct identification.

Material. About 544 specimens from samples in the Austin Collection housed in the NHMUK, London. Sixty elements from sample CLP-6 in the Alba Formation at Las Portillas del río Nevandi section (Spain; see location in Sanz-López et al., 2018).

Remarks. Variation in P1 element ornamentation is associated with element size in ontogenetic series according to Gatovskii \& Zhorina (2014). Four morphotypes may be differentiated. A few nodes located on each side of the cup join to form a row of nodes in the typical morphotype (Figs 2a-2b, 2e, 2j-21). Another morphotype shows short transverse ridges instead of nodes (Figs $2 \mathrm{c}, 2 \mathrm{f}, 2 \mathrm{~m}$ ). The ridges are higher at the middle part of the row, where they are laterally displaced with respect to other ridges or nodes of the row (Figs 2c, 2e, 2h, 2i). The two rows of ridges taper to the dorsal carina where isolated nodes form a $\mathrm{V}$ that opens to the lower ventral part of the cup. This morphotype was described as Gnathodus cf. homopunctatus by Belka $\&$ Groessens (1986) and occurs together with the typical morphotype from the lowermost Viséan beds in Belgium. The ridges are normally well developed in large specimens (Figs 2i, 2m). A third morphotype shows a wide veil and a swollen area limited to the proximal ventral cup (Fig. 2d). A fourth morphotype differs by the occurrence of two rows of nodes developed on one side of the cup (Figs 3g1-3g2). All four morphotypes are observed together in the earliest Viséan sample CLP-6 from the Cantabrian Mountains.

Occurrence. Pseudognathodus homopunctatus first occurs just above the base of the Viséan in Belgium, the British Isles and China (Conil et al., 1989; Devuyst et al., 2003; Poty et al., 2006). Pseudognathodus homopunctatus is a widely distributed species that is used to define the Ps. homopunctatus Zone (Higgins, 1985) in England, a local-range zone (Metcalfe, 1981), or an assemblage zone (Varker \& Sevastopulo, 1985), and a subzone in Belgium (Groessens, 1975). The last occurrence is in the Serpukhovian, Pendleian Regional Stage in England (Higgins, 1985). It has been reported from Europe, northern Africa, Moscow Basin, South Urals, central Asia and China (Qi \& Wang, 2005; Nemyrovska et al., 2006; Nikolaeva et al., 2009; Nigmadhaznov et al., 2010; Kabanov et al., 2016; among others).

In North America, Ps. homopunctatus occurs in the Meramecian beds (middle Viséan) of the Saint Louis Limestone in Kansas and the Thalequah Limestone in Oklahoma (Thompson \& Goebel, 1969; Godwin et al.,

Figure 2. (a-m) Pseudognathodus homopunctatus (Ziegler). a1-a2) Specimen NHMUK PM X 3955). b1-b2) NHMUK PM X 3978. (c1-c2) NHMUK PM X 3950 from sample Cl. 12A, Island Slumped Series in Countie Clare (Ireland). d) Specimen (NHMUK PM X 3915 from sample 2b, Caninia Beds, Arundian of Flintshire (North Wales) in Aldridge et al. (1968). e) Specimen NHMUK PM X 3940. f1-f2) Specimen NHMUK PM X 3943. g1-g2) NHMUK PM X 3941. h) NHMUK PM X 3951. i1-i2) NHMUK PM X 3944 from sample L. 7. j-m) Specimens DGO 15601-DGO 15604 from sample CLP-6 of the Alba Formation at the las Portillas de río Nevandi section, Spain. n1-n2) Pseudognathodus symmutatus (Rhodes et al.), re-illustrations of holotype NHMUK PM X 134, sample 3D 10 from North Crop (South Wales). 
2010). It was described from the basal Chesterian beds (upper Viséan) in the Chainman Formation in Nevada and Utah (Sandberg et al., 1980; Tynan, 1980) and from equivalent or younger beds in California (Stevens et al., 1996), Virginia (Chaplin, 1984) and British Columbia (Orchard, 1987; Beatty, 2002). A probable late Osagean (early Viséan) occurrence was reported from Alaska (Dumoulin et al., 2006).

Pseudognathodus lineatus (Austin \& Husri, 1975) (Figs 1c, 3a-3e2, 4f1-4h)

v 1975 Gnathodus commutatus lineatus, Austin \& Husri, p. 52-53, pl. 2, figs 9a-9b; pl. 4, figs 11a-11c.

v * 1975 Gnathodus commutatus multinodosus Higgins, Austin \& Husri, pl. 2, figs 13a-13c.

Material. About 61 specimens from ten samples (B.S. 8, Cl. 3, Cl. 9, Cl. 10. Cl. 11, Cl. 12A, Cl. 12B, Cl. 13, L. 7 and L. 9) in the Austin Collection at NHMUK.

Type material. The holotype (NHMUK PM X 1723) and paratype (NHMUK PM X 1724) previously designated by Austin \& Husri (1975).

Type locality. Sample Cl. 12B, Inishtubrid Beds in the islands of the Shannon Estuary, County Clare, Ireland (see Austin \& Husri, 1975).

Revised diagnosis. P1 element shows a sub-triangular cup with the widest part close to the ventral margin. The central part of the cup is a high terrace supporting variable ornamentation of a few nodes, a single row of nodes on each side of the carina, which may be replaced by an elongate belt of small nodes. Blade is high in the central part of the carina-blade and is decreasing in height towards the dorsal and ventral ends.

Description. The cup is as long as wide, sub-triangular to sub-rhombic in shape, and sub-circular in smaller specimens. It shows a proximal, central and high terrace bordered by a flared marginal area. Ornamentation is concentrated towards the margin of the terrace, away from the carina. It consists of nodes or short ridges in immature specimens, usually a single row of nodes on each side of the carina, or rarely an elongate belt of small nodes at the margins of the terrace and only a row of nodes at the dorsal termination.

Remarks. Specimens with cups of sub-circular outline in Ps. lineatus are morphologically close to elongated elements of Ps. homopunctatus, because a row of nodes or short ridges may be present in both. The blade in both taxa is identical, but the occurrence of the terrace bordered by a veil is characteristic of Ps. lineatus. In our opinion, many elements identified as G. c. lineatus in the slides of the Austin Collection belong to Ps. homopunctatus. A strongly ornamented row of nodes is present in mature elements of Ps. homopunctatus.

The holotype of Ps. lineatus Austin \& Husri (1975, pl. 2, fig. 9) was smaller than that of Ps. mermaidus (pl. 4, fig. 10), and showed poorly developed ornamentation in two short rows (compare Fig. 4f1 and Fig. 4c1). Specimens identified in slides of the Austin collection with the label Gnathodus commutatus lineatus are Ps. mermaidus, because mineral overgrowth obscured the irregular distribution of small nodes. This can only be seen under the SEM.

The element illustrated as paratype (Austin \& Husri, 1975, pl. 4, figs 11a, 11b) is close to Ps. homopunctatus, and is differentiated by the sub-rhomboidal outline of the cup and the ornamentation of two short and strong rows of nodes (Fig. 4g).

Pseudopolygnathus lineatus shows a longitudinally elongate cup, and not a cup expanded at the rostral and caudal sides of the blade as in ornamented specimens of Lochriea. The denticles of the ventral part of the blade are lower than those in the middle part of the blade.

Occurrence. In the Austin Collection, this species is only known in samples from south central Ireland (Austin \& Husri, 1975). It occurs in Asbian to Brigantian samples from the Durnish, Parsonage and Corgrig Lodge formations in County Limerick; Lords Rock Limestone, Island Slumped Series and Inishtubrid Beds of the Island succession, Inch Bridge limestones, Ballycorick Chert and Reef of the mainland succession in County Clare.

Pseudognathodus mermaidus (Austin \& Husri, 1975) (Figs 3f1-3i2, 4c1-4d2, 5a1-5a2)

p 1967 Gnathodus homopunctatus Ziegler, Spassov \& Filipović, pl. 8, fig. 8 (only).

v* 1975 Gnathodus symmutatus mermaidus, Austin \& Husri, p. 54-55, pl. 2, figs 11a-11c; pl. 4, figs 10a-10c.

p 1987 Paragnathodus (?) homopunctatus, Barskov et al., pl. 16, fig. 6 (only).

1991 Gnathodus sensu lato mermaidus, Stone, p. 29, pl. 3, figs 5, 6 .

p 1993 Pseudognathodus homopunctatus, Perret, p. 349, 351, fig. 122C; pl. C5, fig. 25 (only).

p 1998 Pseudognathodus homopunctatus, Perri \& Spalletta, pl. 2, fig. 13 (only).

1999 Pseudognathodus mermaidus, Meischner \& Nemyrovska, pl. 4, figs 1-3. 
2012 Lochriea homopunctatus, Atakul-Özdemir et al., p. 1288, figs 2A?, B?, C-G.

Material. About 66 specimens from nine samples in the Austin Collection, NHMUK (Cl. 3, Cl. 5, Cl. 10. Cl. 11, Cl. 12A, Cl. 12B, L. 5, L. 7, and L. 10).

Type Material. The holotype and paratype of $G$. symmutatus mermaidus are lost. The holotype of $P S$. mermaidus (NHMUK PM X 1755) was from sample $\mathrm{Cl}$. 5 in the Mermaid Beds (Inishloe Island) of County Clare, Ireland (not Cl. 15 as reported by Austin \& Husri, 1975, p. 54). The paratype (NHMUK PM X 1754) came from sample $\mathrm{Cl} .12 \mathrm{~B}$ in the Inishtubrid Beds of the Islands in the Shannon Estuary (Austin \& Husri, 1975).

Remarks. The well-developed platform shows a curved oral outline, as in other species of Pseudognathodus, but ornamentation consists of many small nodes on the oral surface on both rostral and caudal sides. Several authors accepted the species (Belka, 1985; Stone, 1991; Meischner \& Nemyrovska, 1999), whereas others included it in the variation of Ps. homopunctatus (Metcalfe, 1981; Perret, 1993). In our opinion, a significant characteristic is the thickening of the cup that rises as a terrace above the veil. The ornamentation is concentrated on the proximal cup adjacent to the blade, whereas the margins of the cup are smooth. Nodes can be fused into irregular lines except in the dorsal part, where they tend to be arranged in two rows displaying an acute angle with the carina.

We consider that a small number of the specimens classified as Ps. mermaidus by Austin \& Husri (1975) correspond to specimens of Ps. homopunctatus with overgrowths of apatite crystals observed under high magnification (samples B.S. 10 and B.S. 11 from the upper beds of the Rathkeale Formation at Durnish Point; samples L. 12a and L. 12b in the Shanagolden Formation, County Limerick; sample Cl. 5 in the Mermaid Beds in County Clare). Under the light microscope, the apatite crystals appear similar to irregularly distributed nodes. We were not able to identify any specimen of Ps. mermaidus in slide labelled "G. multi?, G. symm and G. homo" from sample Cl. 5, despite the table in Austin \& Husri (1975, fig. 18) suggesting that two specimens and the holotype of G. s. mermaidus were present in sample Cl. 5. Typical specimen NHMUK PM X 3953 was taken from sample Cl. 12B that was the original sample of the lost paratype (Figs. $3 \mathrm{i} 1$ and 3i2). Other typical specimens were selected from sample L. 7 (NHMUK PM X 3946 and NHMUK PM $\mathrm{X}$ 3942; Figs 3f and 3h) from the Parsonage Formation near Corgrig Lodge, County Limerick.

The ontogenetic series of the P1 element illustrated by Atakul-Özdemir et al. (2012) shows small elements with Ps. homopunctatus morphology together with large (mature) elements of Ps. mermaidus. This suggests that Ps. mermaidus was derived from Ps. homopunctatus. Identification of Ps. mermaidus requires large elements, because immature specimens can not be differentiated from Ps. homopunctatus.

Occurrence. Stone (1991) indicated the Ps. mermaidus ranges between the Arundian and the Asbian English substages (Viséan) on basis of the distribution described by Austin \& Husri (1975). However, this distribution should be revised following our study of the assemblage slides of Austin \& Husri (1975). Pseudognathodus mermaidus was found in the Shanagolden Limestones and the Corgrig Lodge Beds. The holotype of Ps. mermaidus comes from sample Cl. 5 in the Mermaid Beds (Inishloe Island, Ireland). The assemblage slide for sample $\mathrm{Cl}$. 5 (NHMUK PM X 2170) only has the annotation "G. multi?" (probably meaning "G. c. multinodosus"), but no indication that Ps. mermaidus is present. We were not able to find an additional couple of elements in this slide. Austin \& Husri (1975, fig. 18) suggested that Ps. mermaidus specimens should be present but only Ps. homopunctatus was found in the slide. Consequently, an early and rare occurrence of Ps. mermaidus in lower Viséan beds in the Shannon islands is concluded on basis of one element (the holotype). The upper beds of the Rathkeale Beds at the Durnish Point (County Limerick) and the Shanagolden Limestone in the Shanagolden area (samples L. 12a and L. 12b) contain a few doubtful elements here identified as Ps. homopunctatus. Pseudognathodus mermaidus occurs in the Durnish Limestone (samples L. 5 and B.S. 8, Austin \& Husri, 1975, figs 8 and 14) with Lochriea saharae and above the occurrence of $L$. cf. commutata (sample L. 2). It is also present in the Shanagolden, Parsonage and Corgrig Lodge formations near Corgrig Lodge (Austin \& Husri, 1975, fig. 14). In Clare County, it is rare in the upper Lords Rock Limestone, but occurs in the Island Slumped Series and the Inishtubrid beds, where it co-occurs with the upper Viséan Lochriea nodosa of the Shannon Basin (sample Cl. 12B).

Specimens of Ps. mermaidus from the Hodder Mudstone Formation, in the Craven Basin (England), were assigned to the Arundian (lower Viséan) by AtakulÖzdemir et al. (2012). Typical elements occur in the middle Viséan Gnathodus praebilineatus Zone above the first occurrence of L. commutata and in the Entogonites nasutus Ammonoid Zone, below the first occurrence of Gnathodus romulus in the Rhenish Mountains, Germany (Meischner \& Nemyrovska, 1999). Specimens here considered as Ps. mermaidus were illustrated from the Cantabrian Mountains, the Carnic Alps, Serbia and the Russian Platform (Spassov \& Filipović, 1967; Park, 1983, pl. 4, fig. 33; Barskov et al., 1987; Perri \& Spalletta, 1998). Consequently, we suggest Ps. mermaidus ranges from the Arundian to the Brigantian (early Viséan to early Serpukhovian). 


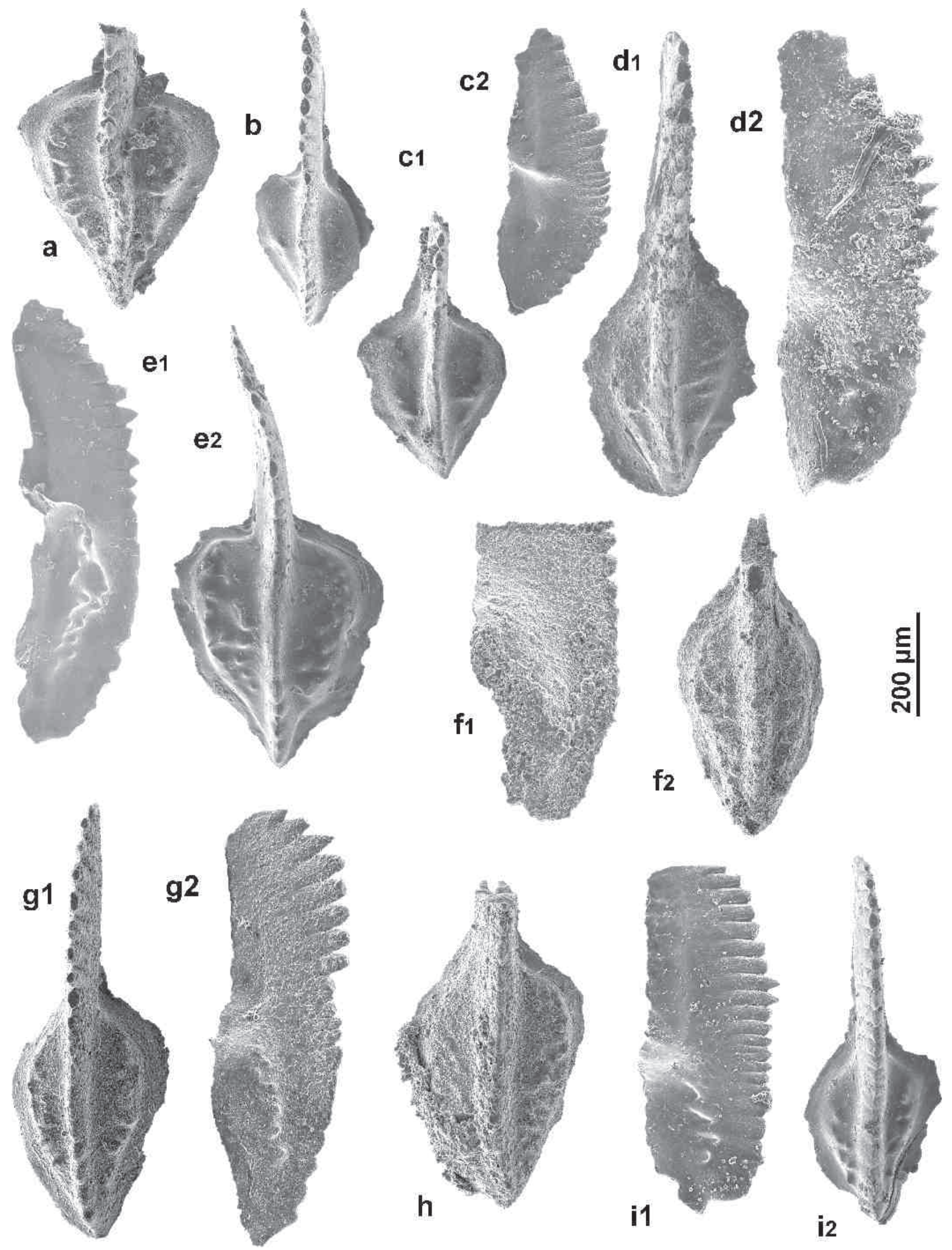


Pseudognathodus posadachaconae sp. nov. (Figs 4e, 5b1-5e2)

v 1968 Gnathodus symmutatus Rhodes et al., Aldridge et al., table 1 .

p v1968 Gnathodus commutatus (Branson \& Mehl), Aldridge et al., table 1.

p v1968 Gnathodus homopunctatus (Ziegler), Aldridge et al., table 1 .

p 1981 Gnathodus homopunctatus, Metcalfe, p. 27, pl. 5, fig. 2 (only).

Derivatio nominis. Named after Luis C. Sánchez de Posada and M. Luisa Martínez Chacón for their palaeontological contributions to knowledge of the Cantabrian Mountains.

Material. Specimens from the Cyathaxonia Beds in Flintshire (North Wales), 55 elements from samples 4Aa to $4 \mathrm{Ac}, 4 \mathrm{Ba}, 4 \mathrm{Bb}, 4 \mathrm{Bd}$ and $4 \mathrm{Be}$ in Aldridge et al. (1968).

Holotype and paratype. Holotype NHMUK PM X 3784 and paratype NHMUK PM X 3857 (Figs 5b1-5c2).

Type locality. Sample 4Ac studied by Aldridge et al. (1968) from the lower part of the Prestatyn Limestone, Flintshire, North Wales.

Diagnosis. Elements with a dorsal carina forming a curve and high outline in lateral view, which may be twice the height of the denticles of the ventral blade. The denticles of the dorsal carina are fused in a ridge, and the dorsal margin is high and straight. Oval cup occupies less than half the length of the element and is smooth or bears a few small, rounded nodes on either sides of the carina.

Description. Mature specimens with blade and carina that consists of 20-23 denticles. Denticles are tall and discrete on the blade but more fused at the dorsal carina, except their isolated triangular tips. Large specimens have more fused dorsal denticles. The blade is high, decreasing in height at the ventral end. The carina is up to twice the height on the fixed blade than on the free blade. A wall or high palisade is developed in the half where the basal cavity is expanded. The oral margin is curved, particularly in the fused half of the carina and decreases in height to the dorsal end. The dorsal end is high and at right angle to the longitudinal plane of the specimen. In lateral view, the outline may be straight or concave outward, with a slightly protruding end of the carina. The cup is moderately wide and its length is less than half the length of the element. The cup is smooth or develops a short, narrow step adjacent to each side of the carina in the dorsal region. These steps may be smooth, with one small, rounded node only on one side, or two to three nodes on either side of the element. The nodes also occur in small specimens.

Remarks. The tall and well-developed dorsal carina differentiates this species from Ps. symmutatus, whose denticles in the dorsal carina are isolated and decrease in height toward the dorsal end. The cup is shorter and better developed that in Ps. symmutatus. Immature specimens of Ps. homopunctatus may be confused with this new species as there are a few nodes developed on the cup. However, the nodes are smaller in mature elements of Ps. posadachaconae sp. nov., and the denticulation and height of the carina is clearly different. We suggest this new species could be derived from Ps. homopunctatus through the loss of ornamentation and a smaller cup with a strong carina.

Occurrence. Metcalfe (1981) included this morphotype in Ps. homopunctatus from the upper Holkerian beds at the top of the Cephalopod Shales at Ings Beck (Craven Basin, England). Specimens from the Cyathaxonia Beds in Flintshire (North Wales) described by Aldridge et al. (1968) correspond to the lower part of the Prestatyn Limestone, developed basinal to the "knoll-reef" in the Asbian Loggerheads Limestone (Somerville et al., 1986; Davies et al., 2011). Pseudognathodus posadachaconae sp. nov. occurs with other shallow-water dwellers such as Hindeodus cristula (Youngquist \& Miller), Mestognathus beckmanni Bischoff, Synclydagnathus geminus (Hinde), and together with a few elements of Gnathodus pseudosemiglaber Thompson \& Fellows, Lochriea saharae Nemyrovska et al. and Vogelgnathus campbelli Rexroad. Sample 4Ae included fragments of probable L. commutata (Branson \& Mehl) and two elements of Vogelgnathus pesaquidi Purnell \& von Bitter.

\section{Pseudognathodus symmutatus (Rhodes, Austin \& Druce, 1969)}

(Figs 1a, 2n1-2n2, 4a1-4a2)

Figure 3. a-e) Pseudognathodus lineatus (Austin \& Husri). (a) Specimen NHMUK PM X 3947 from sample Cl. 12A. (b) Specimens NHMUK PM X 3954, (c1-c2) NHMUK PM X 3952. (d1-d2) NHMUK PM X 3938. (e1-e2) NHMUK PM X 1725 from sample Cl. 12B. f-i) Pseudognathodus mermaidus (Austin \& Husri). f1-f2) Specimen NHMUK PM X 3946 from sample L. 7. g1-g2) Specimen NHMUK PM X 3939, sample L. 7. h) Specimen NHMUK PM X 3942, sample L. 7. i1-i2) Specimen NHMUK PM X 3953 from sample Cl. 12B. 


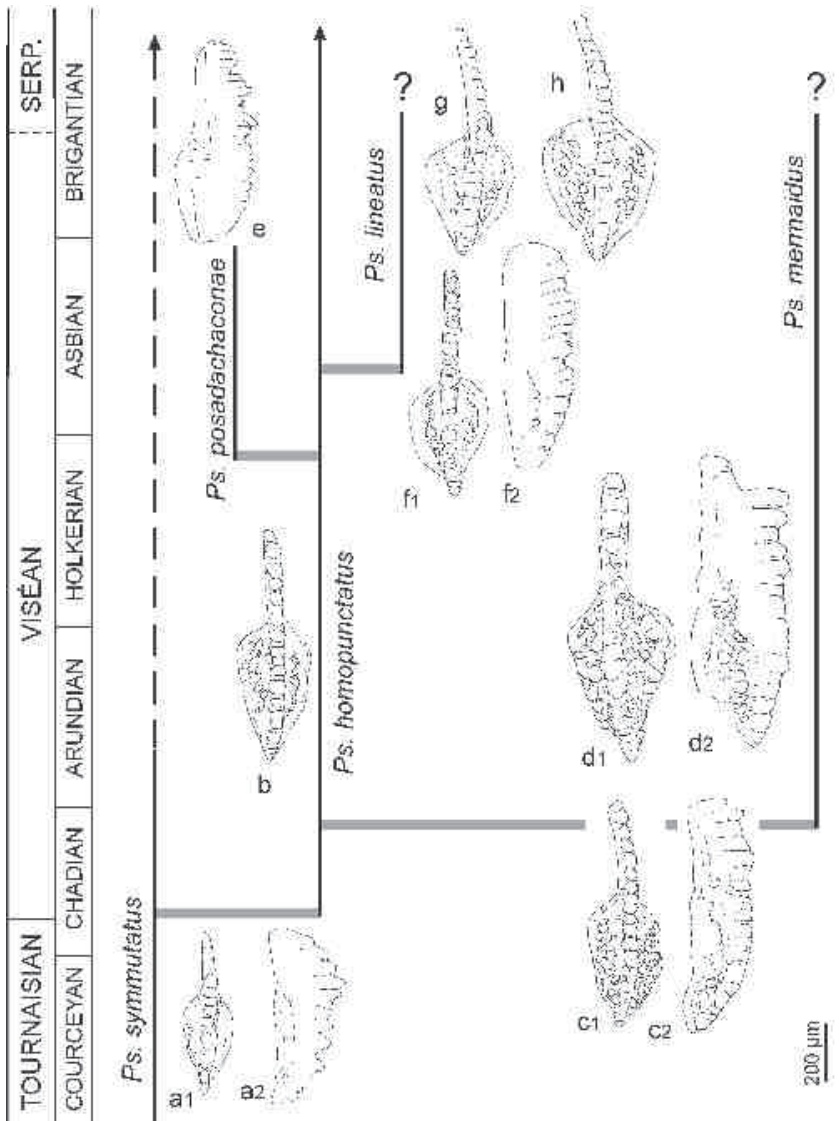

Figure 4. Proposed phylogeny of Pseudognathodus species based on the morphology of the P1 element and stratigraphic ranges plotted against British Regional stages for the upper Tournaisian and Viséan. a1-a2) Pseudognathodus symmutatus (Rhodes et al.), NHMUK PM X 1750, sample L. 7. b) Pseudognathodus homopunctatus (Ziegler), NHMUK PM X 1753, sample Cl. 5. c1-d2) Pseudognathodus mermaidus (Austin \& Husri), holotype NHMUK PM X 1755 and paratype NHMUK PM X 1754. e) Pseudognathodus posadachaconae sp. nov., paratype NHMUK PM X 3857. f-h) Pseudognathodus lineatus (Austin \& Husri), sample C1. 12B. (f1-f2) Holotype NHMUK PM X1723. (g) Paratype NHMUK PM X1724. (h) Specimen NHMUK PM X1725.

? * v 1969 Gnathodus symmutatus, Rhodes et al., 108, pl. 19, figs 1a-4c.

p v 1975 Gnathodus symmutatus symmutatus, Austin \& Husri, pl. 4, figs 7a-7c (only).

non 1975 Gnathodus symmutatus, Higgins, p. 34, pl. 10, figs 8-9 [= Lochriea commutata (Branson \& Mehl)].

1976 Gnathodus symmutatus, Groessens in Conil et al., pl. 6, fig. 19.

1977 Gnathodus symmutatus symmutatus, Perret, pl. 1, fig. 24. p? 1978 Gnathodus symmutatus, Kozitskaya et al., pl. 11, fig. 4 (only)

non1987 Paragnathodus (?) symmutatus, Barskov et al., pl. 16, figs 1-2 (= Lochriea commutata).

1991 Gnathodus sensu lato symmutatus, Stone, p. 2930, pl. 3, figs 7-9.

1993 Pseudognathodus symmutatus, Perret, p. 351, fig. 122B (1).

1996 Paragnathodus symmutatus, Vorontzova in Einor et al., pl. 42, fig. 28.

non 1999 Pseudopolygnathus symmutatus, Meischner \& Nemyrovska, pl. 4, fig. 6 (= Lochriea commutata).

Material. Holotype (NHMUK PM X 134), paratypes (NHMUK PM X 135, NHM PM X 136), 38 specimens from samples CYD 7 to 3D 14/15 from North Crop (South Wales), material studied by Rhodes et al. (1969) and about 100 specimens from Austin \& Husri (1975).

Type locality. Sample 3D 10 from Mellte Bridge, at the confluence of the rivers Mellte and Sychryd near Craig-yDinas, in North Crop (South Wales), according to Rhodes et al. (1969).

Revised diagnosis. Element with a convex oral outline of a slightly expanded cup tapers at both ends. Ornamentation is lacking or a small node (rarely two) is located on the cup. Blade with high denticles, except the lower at the ventral portion. The dorsal carina shows denticles decreasing in height.

Remarks. The original diagnosis indicated that $P S$. symmutatus has a small, unornamented cup (Rhodes et al., 1969). Stone (1991) suggested that it is not possible to differentiate immature specimens of Ps. homopunctatus from Ps. symmutatus. This is illustrated by the type material designed by Rhodes et al. (1969; compare pl. 19, figs 1-4 with figs 5-8). These are small, probably immature elements, and occur with larger specimens assigned to Ps. homopunctatus in the same samples. The holotype NHMUK PM X 134 (sample 3D 10) has a small node in the rostral part of the cup and the paratype, NHMUK PM X 135, from the same sample a small indentation. The latter is the smallest of the observed type specimens. Paratype NHMUK PM X 136 (sample 3d 14/15) has a small node on the caudal part of the cup. Perret (1993) included specimens with a small node in Ps. symmutatus, which she considered transitional to Ps. homopunctatus.

Minute P1 elements with Ps. symmutatus morphology and without node or indentation, are interpreted as a very early stage in the growth of Ps. homopunctatus in samples studied by us from the Cantabrian Mountains and the 
Pyrenees. This conclusion is based on a full ontogenetic series showing a range of sizes, and the progressive development of ornamentation. However, large specimens assigned to Ps. symmutatus seem to be illustrated from Belgium by Conil et al. (1976) and a detailed description of this material needs to be undertaken. The mature elements studied by Austin \& Husri (1975), Stone (1991) and Perret (1993) show a smooth cup which occupies more than half the length of the element. One or two small nodes may be present on the dorsal part of the cup. The oral denticulation of the carina consists of wide, triangular teeth that become narrower at the ventral part of the blade. The height is lower at the margins than at the central part of the blade.
Occurrence. Pseudognathodus symmutatus may have inhabited more onshore environment than typical Ps. homopunctatus according to Stone (1991). In Belgium and China, Ps. symmutatus has been recovered from older beds than Ps. homopunctatus (Conil et al., 1976; Tian \& Coen, 2005). It ranges from the uppermost Tournaisian to lowermost Viséan, from beds with Scaliognathus anchoralis and Mestognathus praebeckmanni, to beds at the first occurrence of $M$. beckmanni (Conil et al., 1976, 1988). It was reported at the last occurrence of S. anchoralis in the Pyrenees (Marks \& Wensink, 1970; Boersma, 1973; Perret, 1993). Further work is required to verify the status of Ps. symmutatus and its last occurrence in upper Viséan to Serpukhovian beds.
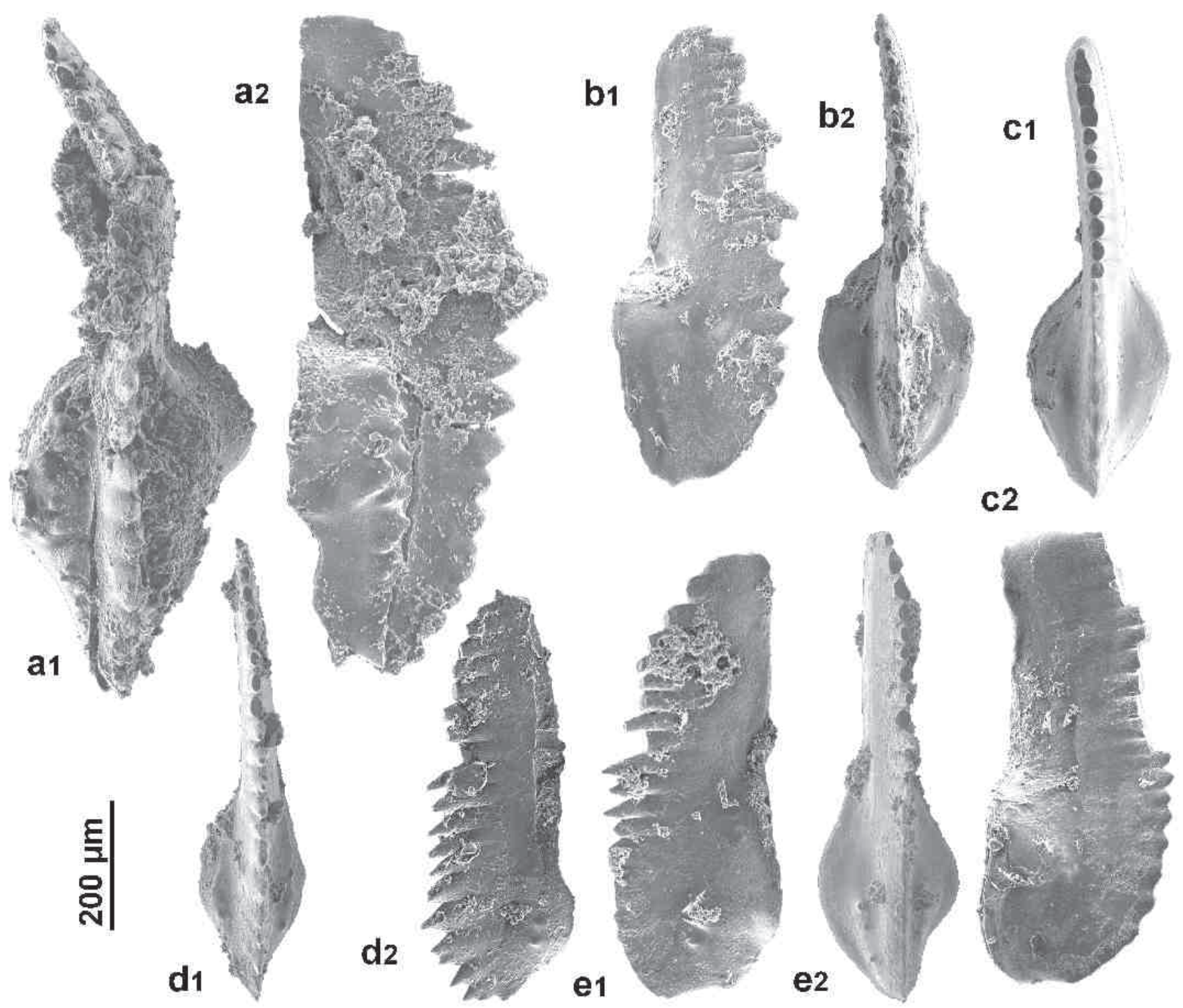

Figure 5. a1-a2) Pseudognathodus mermaidus Austin \& Husri, specimen NHMUK PM X 3949, sample Cl. 12A. b-e) Pseudognathodus posadachaconae sp. nov. (b1-b2) Paratype NHMUK PM X 3857 from sample 4Ac. (c1-c2) Holotype NHMUK PM X 3784 from sample 4Ac. (d1-d2) Specimen NHMUK PM X 3866 from sample 4Ba. (e1-e2) Specimen NHMUK PM X 3865 from sample $4 \mathrm{Ba}$. 


\section{VALIDITY AND DISTRIBUTION OF PSEUDOGNATHODUS}

The late Tournaisian Ps. symmutatus is the oldest known species of Pseudognathodus in the stratigraphic record (Fig. 4). The origin of this species is unknown, although it is usually assumed to be derived from a species with a spathognathodid P1 element. Tian \& Coen (2005) proposed a derivation from "Spathognathodus" macer Branson \& Mehl, although their P1 elements are very distinct, in our opinion. Pseudognathodus homopunctatus evolved from Ps. symmutatus developing rows of nodes or short ridges in its growth. It dispersed worldwide just above the lower boundary of the Viséan (Fig. 4). Pseudognathodus mermaidus evolved from Ps. homopunctatus developing a proximal terrace ornamented by many small nodes in the lower Viséan (Arundian). Pseudognathodus mermaidus seems to have a moderately wide distribution in northern Europe and the Russian platform (Fig. 6). The P1 element of Ps. posadachaconae sp. nov. shows a high, rostral carina and a slow rate of development through ontogeny of cup and ornamentation, which may be lacking, during the growth of element. The morphology is similar to mature, large Ps. symmutatus, but the common occurrence of nodes in immature elements suggests a derivation from $P S$. homopunctatus. It is known from upper Holkerian to Asbian and only in the North Wales and English Craven extensional basins (Fig. 6).

Pseudognathodus lineatus probably evolved in the Asbian (upper Viséan) from Ps. homopunctatus through the modification of the wide and triangular cup with a proximal terrace. The ornamentation of ridges and nodes suggests a convergent evolution with ornamented species of Lochriea that diversified in the Brigantian (Barham et al., 2015). Pseudognathodus lineatus is considered to be restricted to southwestern Ireland (Fig. 6).

The last occurrence of Pseudognathodus seems to be in the Serpukhovian, probably in the lower part and for the widerange and cosmopolitan species, Ps. homopunctatus and $P s$. symmutatus (Figs 4, 6). However, stratigraphic ranges may be open to conjecture because differentiation of immature specimens of Ps. symmutatus and Ps. homopunctatus cannot be done without a well-preserved ontogenetic series including adult growth. There is a similar situation for immature specimens of Ps. homopunctatus and Ps. mermaidus.

The phylogeny of Pseudognathodus based on P1 elements shows different trends to other lineages, or clades such as the related Protognathodus and Gnathodus. This distinctive evolutionary history suggests that the genus Pseudognathodus is valid based on changes in the P1 element. Knowledge of the full apparatus will also help to decipher the origin and to show the relationships with other genera and families. The homeomorph genus Protognathodus evolved from the latest Devonian to the late Tournaisian from a smooth cup-species to a diversely ornamented species (Lane et al., 1980). During the upper Viséan and Serpukhovian, the genus Lochriea had more diverse and ornamented species. This time also marked the widest diversity of Pseudognathodus (Asbian to Brigantian). However, this diversity is known only from the British Isles and Ireland, and some species (Ps. lineatus and Ps. posadachaconae sp. nov.) seem to have been strongly restricted ecologically, with short stratigraphic ranges suggesting that they were specialist taxa. In contrast, Ps. homopunctatus and Ps. symmutatus seem to have been generalist taxa with a wide distribution from shallow-water to deep-water settings of the Palaeo-Tethys. Abundant small specimens and poorly ornamented elements occur in samples from deep-water basins, for example in Spain (BlancoFerrera et al., 2005).

Pseudognathodus does not seem to have dispersed widely in the basins of North America (Fig. 6). Probable early Viséan (late middle Osagean) occurrences of Ps. homopunctatus are described only in northern Alaska (de Long Mountains) by Dumoulin et al. (2006) and rare occurrences have been reported from the Meramecian Regional Substage (middle Viséan) in Kansas and Oklahoma (Thompson \& Goebel, 1969; Godwin et al., 2010). In other North American basins, it occurred from the basal Chesterian Substage (as in Utah and California) or Chesterian beds, upper Viséan (Virginia and Quesnel Terrane of British Columbia, Canada) (Sandberg et al., 1980; Tynan, 1980; Chaplin, 1984; Orchard, 1991; Beatty, 2002). The first occurrence of Ps. homopunctatus in Utah is notable as it is below the diverse ammonoid faunas of the Asbian (Korn \& Titus, 2011), and from beds recording the first occurrence of Gnathodus bilineatus. Consequently, wide diversification of Pseudognathodus on the southern margin of the Laurussian landmass seems to be consistent with dispersion of Pseudognathodus in the carbonate platforms and basins of North America.

\section{CONCLUSIONS}

Pseudognathodus is a valid genus differentiated from other conodont genera by the morphology of the P1 element and its evolutionary history. Upper Tournaisian Ps. symmutatus with an unornamented cup led to Ps. homopunctatus and this to different ornamented species. Immature specimens are difficult to differentiate and mature elements are needed to distinguish closely related species. Diagnostic specific characteristics tend to only be developed within mid-large sized specimens. The species diversity of Pseudognathodus increased in the upper Viséan. Endemic Ps. lineatus and Ps. posadachaconae sp. nov. (and maybe Ps. mermaidus) evolved from Ps. homopunctatus, which was widely distributed geographically and stratigraphically. 


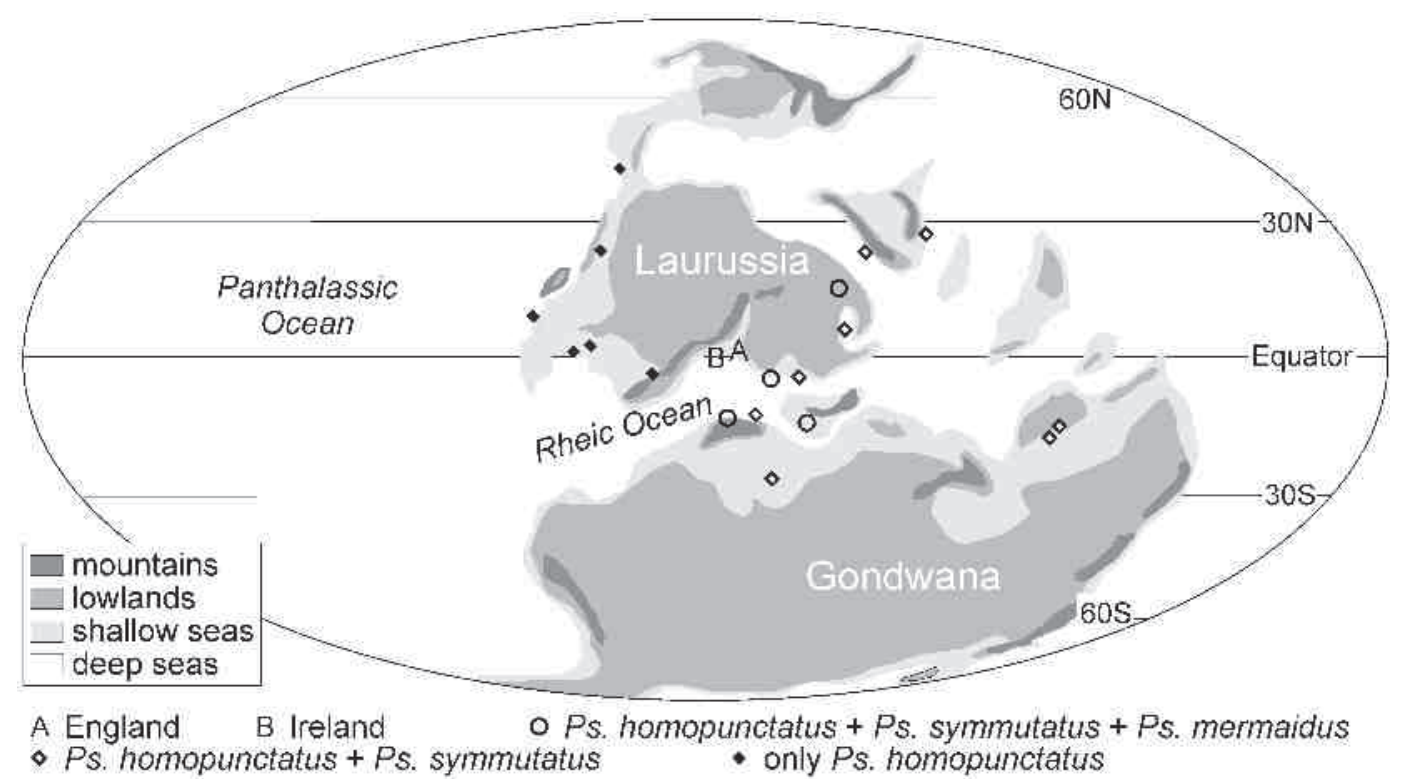

Figure 6. Viséan palaeogeography (from Rowley et al., 1985) showing the distribution of Pseudognathodus.

\section{ACKNOWLEDGEMENTS}

We are very pleased to contribute to the volume in honour of professors Luis C. Sánchez de Posada and M. Luisa Martínez Chacón. J. S-L received financial support from SYNTHESIS 1 project (Application GB-TAF-4210, 2008) of the European Union. JS-L and SB-F benefited from support via the project CGL2016-78738 of the Spanish Ministerio de Economía y Competitividad. Finally, we would like to thank George Sevastopulo, an anonymous reviewer and the editors Carmen Álvarez-Vázquez and Elisa Villa for their useful comments and suggestions.

\section{NOMENCLATURAL ACT}

This published work and the nomenclatural acts it contains have been registered in ZooBank, the proposed online registration system for the International Code of Zoological Nomenclature. The ZooBank LSIDs (Life Science Identifiers) can be resolved and the associated information viewed through any standard web browser by appending the LSID to the prefix "http://zoobank.org/". The LSIDs for this publication are BF94715F-9C884A49-B092-29E8B48CD3EC (Pseudognathodus Perret, 1993), 3C12E001-AC29-49DD-8877-90DEADAE6789 (Pseudognathodus lineatus Austin \& Husri, 1975), and FC71B345-D4F5-4CA5-A2F6-8E1C8515ECD0 (Pseudognathodus posadachaconae sp. nov.).

\section{REFERENCES}

Aldridge, R.J., Austin, R.L. \& Husri, S. 1968. Viséan conodonts from North Wales and Ireland. Nature, 219, 255-258; doi:10.1038/219255a0.

Atakul-Özdemir, A, Purnell, M.A. \& Riley, N.J. 2012. Cladistic tests of monophyly and relationships of biostratigraphically significant conodonts using multielement skeletal data - Lochriea homopunctatus and the genus Lochriea. Palaeontology, 55, 1279-1291; doi: 10.1111/j.1475-4983.2012.01190.x.

Austin, R.L. 1987. Conodonts of the Arundian (Dinantian) stratotype boundary beds from Dyfed, South Wales. In: Micropalaeontology of Carbonate Environments (ed. Hart, M.). British Micropalaeontological Society Series, Ellis Horwood Ltd. Chichester, 238-245.

Austin, R.L. \& Aldridge, R.J. 1973. Conodonts from horizons with Goniatites crenistria Phillips in North Wales and Isle of Man. Geological Magazine, 110, 37-42.

Austin, R.L. \& Davies, P.B. 1984. Problems of recognition and implications of Dinantian conodont biofacies in the British Isles. In: Conodont Biofacies and Provincialism (ed. Clarke, D.J.). Special Paper of the Geological Society of America, Boulder, Colorado, 196, 195-228.

Austin, R.L. \& Husri, S. 1975. Dinantian conodont faunas of County Clare, County Limerick and County Leitrim. An Appendix. In: International Symposium Namur on 1974 (eds. Bouckaert, J. \& Streel. M). Geological Survey of Belgium, Brussels, Publication 3, 18-69, more 15 plates (printed 1974).

Barham, M., Murray, J., Sevastopulo, G.D. \& Williams, M. 2015. Conodonts of the genus Lochriea in Ireland and the recognition of the Viséan-Serpukhovian (Carboniferous) boundary. Lethaia, 48, 151-171; doi:10.111/let.12096. 
Barskov, I.S., Alekseev, S.A., Kononova, L.I. \& Migdisova, A.V. 1987. Predelitel konodontov verkhnego devona i karbona. [Atlas of Upper Devonian and Carboniferous conodonts]. Izdatelstvo Moscovskogo Universiteta, Moscow, 1-144.

Beatty, T.W. 2002. New geological and paleontological data from the Harper Ranch Group, Kamloops, British Columbia. Geological Survey of Canada, Current Research, 2002-A14, 1-9; doi:10.4095/213080.

Belka, Z. 1985. Lower Carboniferous conodont biostratigraphy in the northeastern part of the Moravia-Silesia Basin. Acta Geologica Polonica, 35, 33-60.

Belka, Z. \& Groessens, E. 1986. Conodont succession across the Tournaisian-Viséan boundary beds at Salet, Belgium. Bulletin de la Société belge de Géologie, 95, 257-280.

Belka, Z. \& Lehmann, J. 1998. Late Viséan/early Namurian conodont succession from the Esla area of the Cantabrian Mountains, Spain. Acta Geologica Polonica, 48, 31-41.

Bermúdez-Rochas, D., Sarmiento, G.N. \& Rodríguez, S. 2004. Conodontos del Viseense superior (Carbonífero) de la Unidad de la Sierra del Castillo (Córdoba, España). Coloquios de Paleontología, 54, 25-68.

Bischoff, G. 1957. Die Conodonten-Stratigraphie des rhenoherzynischen Unterkarbons mit Berucksichtigung der Wocklumeria-Stufe und der Devon/Karbon-Grenze. Abhandlungen des Hessischen Landesamtes für Bodenforschung, 19, 1-64.

Blanco-Ferrera, S., García-López, S. \& Sanz-López, J. 2005. Conodontos carboníferos de la sección del río Cares (Unidad de Picos de Europa, Zona Cantábrica, $\mathrm{N}$ de España). Geobios, 38, 17-27.

Blanco-Ferrera, S., Sanz-López, J., García-López, S., Bastida, F. \& Valín, M.L. 2011. Conodont alteration and tectonothermal evolution of a diagenetic unit in the Iberian Variscan belt (Ponga Cuera unit, NW Spain). Geological Magazine, 148, 35-49.

Bless, M.J.M., Bouckaert, J., Bouzet, Ph., Conil, R., Cornet, P., Fairon-Demaret, M., Groessens, E., Longestaey, P.J., Meesen, J.P.M.Th., Paproth, E., Pirlet, H., Streel, M., van Ameron, H.W.J. \& Wolf, M. 1976. Dinantian rocks in the subsurface North of the Brabant and Ardeno-Rhenish massifs in Belgium, the Netherlands and the Federal Republic of Germany. Mededelingen Rijks Geologische Dienst, Nieuwe serie, 27, 81-195.

Boersma, K.T. 1973. Devonian and Lower Carboniferous conodont biostratigraphy, Spanish Central Pyrenees. Leidse Geologische Mededelingen, 49, 303-377.

Buchroithner, M.F. 1979. Die Conodonten Chronologie im Karbon der Pyrenäen. Mitteilungen der Österreichischen Geologischen Gesellschaft, 70, 75-118 (imprint 1977).

Chaplin, J.R. 1984. Conodont biostratigraphy of Lower Carboniferous strata in the southern Appalachians. In: Compte Rendu Neuvième Congrès International de Stratigraphie et de Géologie du Carbonifère (eds. Sutherland, P.K. \& Manger, W.L.). Washington and Champaing-Urbana 1979, 2, 265-281.

Chauff, K.M. 1981. Multielement conodont species from the Osagean (Lower Carboniferous) in Midcontinent North
America and Texas. Palaeontographica, Abteilung A, $175,140-169$.

Chauffe, K.M. \& Nichols, P.A. 1995. Multielement conodont species from the Louisiana Limestone (Upper Devonian) of west-central Illinois and northeastern Missouri, U.S.A. Micropaleontology, 41, 71-186.

Conil, R., Groessens, E. \& Lys, M. 1976. Étude micropaléontologique de la tranchée Yves-Gomezée (Tn3c-V1-V2, Belgique). Bulletin de la Société belge de Géologie, 82, 201-239 (printed 1973).

Conil, R., Groessens, E., Laloux, M. \& Poty, E. 1989. La limite Tournaisien/Viséen dans la region type. Annales de la Société Géologique de Belgique, 112, 177-189.

Conil, R., Groessens, E., Hibo, D., Laloux, M., Lees, A. \& Poty, E. 1988. The Tournaisian-Visean Boundary in the Type Area. Guidebook Field Meeting, Palaeontological Association Carboniferous Group, 22-25 April 1988, University of Leuven, 2 volumes.

Davies, J.R., Somerville, I.D., Waters, C.N. \& Jones, N.S. 2011. Chapter 8: North Wales. In: A Revised Correlation of Carboniferous Rocks in the British Isles (eds. Waters et al.). Geological Society Special Report 26, London, 49-56.

Devuyst, F.X., Hance, L., Hou, H., Wu, X., Tian, S., Coen, M. \& Sevastopulo, G. 2003. A proposed Global Stratotype Section and Point for the base of the Visean Stage (Carboniferous): the Pengchong section, Guangxi, South China. Episodes, 26, 105-115.

Dumoulin, J.A., Harris, A.G., Blome, C.D. \& Young, L.E. 2006. Conodont and radiolarian data from the De Long Mountains quadrangle and adjacent areas. U.S. Geological Survey Open-File Report 2006-1068; accessed January 24, 2011, at http://pubs.usgs.gov/of/2006/1068/.

Dzik, J. 1976. Remarks on the evolution of Ordovician conodonts. Acta Palaeontologica Polonica, 21, 395-455.

Dzik, J. 1997. Emergence and succession of Carboniferous conodont and ammonoid communities in the Polish part of the Variscan Sea. Acta Palaeontologica Polonica, 42, $57-170$.

Einor, O.L. et al. 1996. The former USSR. In: The Carboniferous of the World III, the Former USSR, Mongolia, Middle Eastern Platform, Afghanistan, \& Iran (eds. Wagner, R.H., Winkler Prins, C.F. \& Granados, L.F.). IUGS Publication No. 33, Instituto Geológico y Minero de España/Nationaal Natuurhistorisch Museum, Madrid, 13-404.

Gatovskii, Y.U. \& Zhorina, M.A. 2014. The ontogenesis of several Late Visean conodonts from the Verkhyaya Kardailovka section (Southern Urals). Moscow University Geology Bulletin, 69, 452-457.

Godwin, C., Boardman, D.R. II, Mazzullo, S.J. \& Wilhite, B.W. 2010. Lithostratigraphy and conodont biostratigraphy of the Upper Mississippian Tahlequah Member, Moorefield Formation based on the type locality. Geological Society of America Abstracts with Programs, North-Central Section (44th Annual) and South-Central Section (44th Annual) Joint Meeting, 42 (2), 71.

Groessens, E. 1975. Distribution des conodontes dans le Dinantien de la Belgique. In: International Symposium Namur in 1974 (eds. Bouckaert, J. \& Streel, M.). 
Geological Survey of Belgium, Brussels, Publication 17, 1-193 (printed 1974).

Groessens, E. \& Noël, B. 1977. Étude litho- et biostratigraphique du rocher du Bastion et du Rocher Bayard a Dinant. In: International Symposium Namur on 1974 (eds. Bouckaert, J. \& Streel. M). Geological Survey of Belgium, Brussels, Publication 15, 1-17 (printed 1974).

Groves, J.R., Larghi, C., Nicora, A. \& Rettori, R. 2003. Mississippian (Lower Carboniferous) microfossils from the Chios Mélange (Chios Island, Greece). Geobios, 36, 379-389; doi: 10.1016/S0016-6995(03)00037-8.

Higgins, A.C. 1961. Some Namurian conodonts from North Staffordshire. Geological Magazine, 48, 210-224.

Higgins, A.C. 1962. Conodonts from the "Griotte" limestone of north-west Spain. Notas y comunicaciones del Instituto Geológico y Minero de España, 65, 5-22.

Higgins, A.C. 1975. Conodont zonation of the Late Viseanearly Westphalian strata of the south and central Pennines of northern England. Bulletin of the Geological Survey of Great Britain, 53, 1-90.

Higgins, A.C. 1985. The Carboniferous Subsystem: Part 2 - Conodonts of the Silesian Subsystem from Great Britain and Ireland. In: A stratigraphical Index of Conodonts (eds. Higgins, A.C. \& Austin, R.L.). The British Micropalaeontological Society, Ellis Horwood Limited, Chichester, 210-227.

Higgins, A.C. \& Wagner-Gentis, C.H.T. 1982. Conodonts, goniatites and the biostratigraphy of the earlier Carboniferous from the Cantabrian Mountains, Spain. Palaeontology, 25, 313-350.

Igo, H. 1973. Lower Carboniferous conodonts from the Akiyoshi Limestone Group, Southwest Japan. Transactions and Proceedings of the Palaeontological Society of Japan, 92, 185-199; doi: 10.14825/prpsj1951.1973.92_185.

International Commission on Zoological Nomenclature 1999. International Code of Zoological Nomenclature, Fourth Edition. International Trust for Zoological Nomenclature, London, $306 \mathrm{p}$.

Kabanov, P.B., Aleksev, A.S., Gibshman, N.B., Gabdullin, R.R. \& Bershov, V. 2016. The upper Viséan-Serpukhovian in the type area for the Serpukhovian Stage (Moscow Bain, Russia): Part 1, Sequences, disconformities, and biostratigraphic summary. Geological Journal, 51, 163-194; doi: 10.1002/gj.2612.

Korn, D. \& Titus, A.L. 2011. Goniatites Zone (middle Mississippian) ammonoids of the Antler Foreland Basin (Nevada, Utah). Bulletin of Geosciences, 80, 107-196.

Kozitskaya, R.I., Kossenko, Z.A., Lipnjagov, O.M. \& Nemirovskaya, T.I. 1978. Carboniferous Conodonts of the Donets Basin. Kiev, Izdatel'stvo (Naukova Dumka), 133 pp., 32 pl. (in Russian).

Kullmann, J., Perret-Mirouse, M.F. \& Delvolvé, J.J. 2008. Goniatites et conodontes du Viséen/Serpukhovien dans les Pyrénées centrales et occidentales, France. Geobios, 41, 635-656; doi: 10.1016/j.geobios.2007.09.003.

Lane, H.R., Sandberg, C.A. \& Ziegler, W. 1980. Taxonomy and phylogeny of some Lower Carboniferous conodonts and preliminary post-Siphonodella zonation. Geologica et Palaeontologica, 14, 117-164.

Marks, P. \& Wensink, H. 1970. Conodonts and the age of the "Griotte" Limestone Formation in the Upper Aragon Valley (Huesca, Spain). Koninklijke Nederlandse Akademie van Wetenschappen-Amsterdam, Proceedings, Serie B, 73, 238-275.

Mathews, S.C. 1973. Notes on open nomenclature and on synonymy lists. Palaeontology, 16, 713-719.

Mathews, S.C. \& Thomas, J.M. 1974. Lower Carboniferous conodont faunas from the northeast Devonshire. Palaeontology, 17, 371-385.

Meischner, K.D. \& Nemyrovska, T. 1999. Origin of Gnathodus bilineatus (Roundy, 1926) related to goniatite zonation in Rheinisches Schiefergebirge, Germany. Bolletino della Società Paleontologica Italiana, 37, 427-442.

Menéndez-Álvarez, J.R. 1978. Conodontos de la Formación Genicera en el corte de Entrago (Teverga, Asturias). Breviora Geológica Astúrica, 22, 1-7.

Metcalfe, I. 1980. Conodont faunas and age of the Raygill Quarry Limestones (Embsay Limestone), Lothersdale, Yorkshire. Proceedings of the Yorkshire Geological Society, 43, 169-178.

Metcalfe, I. 1981. Conodont zonation and correlation of the Dinantian and early Namurian strata of the Craven Lowlands of northern England. Institute of Geological Science, Report 80/10, 1-70.

Nemyrovska, T.I. 2005. Late Viséan/early Serpukhovian conodont succession from the Triollo section, Palencia (Cantabrian Mountains, Spain). Scripta Geologica, 129, 13-89.

Nemyrovska, T.I., Perret-Mirouse, M.F. \& Weyant, M. 2006. The early Viséan (Carboniferous) conodonts from the Saoura Valley Algeria. Acta Geologica Polonica, 56, 361-370.

Nigmadhaznov, I.M., Nikolaeva, S.V., Konovalova, V.A. \& Orlov-Labkovsky, O. 2010. Integrated ammonoid, conodont and foraminiferal stratigraphy in the Paltau section, middle Tien-Shan, Uzbekistan. Newsletter on Carboniferous Stratigraphy, 28, 50-60.

Nikolaeva, S.V., Kulagina, E.I., Pazukhin, V.N., Kochetova, N.N. \& Konovalova, V.A. 2009. Paleontology and microfacies of the Serpukhovian in the Verkhnyaya Kardailovka Section, South Urals, Russia: potential candidate for the GSSP for the Viséan-Serpukhovian boundary. Newsletters on Stratigraphy, 43, 165-193.

Orchard, M.J. 1987. Conodont biostratigraphy and correlation of the Harper Ranch Group (Devonian-Permian), Ashcroft map area, southern British Columbia. Current Research, Part A, Paper of Geological Survey of Canada, 87-JA, 743-749.

Orchard, M.J. 1991. Conodonts, time and terranes: an overview of the biostratigraphic record in the western Canadian Cordillera. In: Ordovician to Triassic Conodont Paleontology of the Canadian Cordillera (eds. Orchard, M.J. \& McCracken, A.D.). Bulletin of the Geological Survey of Canada, 417, 1-25.

Park, S.-I. 1983. Zonenfolge, Phylogenie und Taxonomie Karbonischer Conodonten Zwischen Tournai und Westfal 
(Westeuropa). Unpublished Doctoral Thesis, Universitat Marburg.

Pazukhin, V.N., Kulagina, E.I., Nikolaeva, S.V., Kochetova, N.N. \& Konovalova, V.A. 2010. The Serpukhovian Stage in the Verkhnyaya Kardailovka Section, South Urals. Stratigraphy and Geological Correlation, 18, 269-289; doi: 10.1134/S0869593810030044.

Perret, M.-F. 1977. Données récentes de la micropaléontologie dans l'étude du Carbonifére marin des Pyrénées. Annales de la Société Géologique du Nord, 97, 77-85 (imprint 1976).

Perret, M.-F. 1993. Recherches micropaléontologiques et biostratigraphiques (conodontes-foraminifères) dans le Carbonifère Pyrénéen. Strata, 21, 1-597.

Perret, M.-F., Vachard, D., Aguirre, P. \& Crasquin-Soleau, S. 1994. Micropaléontologie des calcaires épibathyaux a Globochaete (Algue, problèmatique) du Carbonifère des Pyrénées. Geobios, 27, 659-675; doi: 10.1016/S00166995(94)80053-7.

Perri, M.C. \& Spaletta, C. 1998. Conodont distribution at the Tournaisian/Visean boundary in the Carnic Alps (southern Alps, Italy). In: Proceedings of the Sixth European Conodont Symposium (ECOS VI) (ed. Szaniawski, H.). Palaeontologica Polonica, 58, 225-245.

Poty, E., Devuyst, F.X. \& Hance, L. 2006. Upper Devonian and Mississippian foraminiferal and rugose coral zonations of Belgium and northern France: a tool for Eurasian correlations. Geological Magazine, 143, 829-857; doi: 10.1017/S0016756806002457.

Purnell, M.A. \& von Bitter, P.H. 1992. Vogelgnathus Norby and Rexroad (Conodonta): new species from the Lower Carboniferous of Atlantic Canada and Northern England. Journal of Paleontology, 66, 311-332.

Purnell, M.A., Donoghue, P.C.J. \& Aldridge, R.J. 2000. Orientation and anatomical notation in conodonts. Journal of Paleontology, 74, 113-122.

Qi, Y. \& Wang, Z. 2005. Serpukhovian conodont sequence and the Viséan-Serpukhovian boundary in south China. Rivista Italiana di Paleontologia e Stratigrafia, 111, 3-10; doi: 10.13130/2039-4942/6260.

Qi, Y., Nemyrovska, T.I., Wang, X., Chen, J., Wang, Z., Lane, H.R., Richards, B.C., Hu, K. \& Wang, Q. 2014. Late Viséan-early Serpukhovian conodont succession at the Naqing (Nashui) section in Guizhou, South China. Geological Magazine, 151, 254-268; doi: 10.1017/ S001675681300071X.

Reynolds, M.J. 1970. A Lower Carboniferous conodont fauna from Flintshire, North Wales. Bulletin of Geological Survey of Great Britain, 32, 1-19.

Rhodes, F.H.T., Austin, R.L. \& Druce, E.C. 1969. British Avonian (Carboniferous) conodont faunas, and their value in local and intercontinental correlation. Bulletin of the British Museum (Natural History), Geology Supplement, $5,1-313$.

Rowley, D.B., Raymond, A., Parrish, J.T., Lottes, A.L., Scotese, C.R. \& Ziegler, A.M. 1985. Carboniferous paleogeographic, phytogeographic, and paleoclimatic reconstructions. International Journal of Coal Geology, 5, 7-42; doi: 10.1016/0166-5162(85)90009-6.
Sandberg, C.C., Poole, F.G. \& Gutschick, R.C. 1980. Devonian and Mississippian stratigraphy and conodont zonation of Pilot and Chainman Shales, Confusion Range, Utah. In: Paleozoic Paleogeography of the WestCentral United States, Rocky Mountain Paleogeography Symposium 1 (eds. Fourch, T.D. \& Magathan, E.R.). Rocky Mountain Section SEPM, Denver, Colorado, 71-79.

Sanz-López, J., Cózar, P. \& Blanco-Ferrera, S. 2018. Discovery of a Mississippian-early Bashkirian carbonate platform coeval with condensed cephalopod limestone sedimentation in NW Spain. Geological Journal, doi: 10.1002/gj.3087.

Skompski, S. 1996. Stratigraphic position and facies significance of the limestone bands in the subsurface Carboniferous succession of the Lublin Upland. Acta Geologica Polonica, 46, 171-268.

Somerville, H.E.A. \& Somerville, I.D. 1999. Late Visean conodont biostratigraphy and biofacies in the Kingscourt area, Ireland. Bolletino della Società Paleontologica Italiana, 37, 443-464.

Somerville, I.D., Mitchell, M. \& Strank, A.R.E, 1986. An Arundian fauna from the Dyserth area, North Wales and its correlation within the British Isles. Proceedings of the Yorkshire Geological Society, 46, 57-75.

Spassov, H. 1965. Unterkarbon in Bulgarien. Reports of the Bulgarian Geological Society, 26, 157-167.

Spassov, H. \& Filipović, I. 1967. Devonian and Carboniferous conodont fauna from north western Serbia. Bulletin of the Geological Institute, Series Paleontology, Bulgarian Academy of Sciences, 16, 53-86.

Spassov, H., Stojanovic-Kuzenko, S. \& Pajic, V. 1969. New research on Paleozoic conodonts in northwestern Serbia. Bulletin of the Institute for Geological and Geophysical Research, Series A, 26, 153-165 (imprint 1968).

Stevens, C.H., Klingman, D.S., Sandberg, C.A., Stone, P., Belasky, P., Poole, F.G. \& Snow, J.K. 1996. Mississippian stratigraphic framework of east-central California and southern Nevada with revision of Upper Devonian and Mississippian stratigraphic units in Inyo County, California. Bulletin of the U.S. Geological Survey 1988J, J1-J39.

Stone, J.J. 1991. Arundian (Lower Carboniferous) conodonts from South Wales. Special Papers in Paleontology, the Paleontological Association, London, 46, 1-163.

Sweet, W.C. 1988. The Conodonta: Morphology, Taxonomy, Paleoecology and Evolutionary History of a Long Extinct Animal Phylum. Oxford Monographs on Geology and Geophysics, 10, 1-212.

Thompson, T.L. \& Goebel, E.D. 1969. Conodonts and stratigraphy of the Meramecian Stage (Upper Mississippian) in Kansas. Kansas Geological Survey Bulletin, 192, 1-56.

Tian, S. \& Coen, M. 2004. Conodont zonation in the Carboniferous Yanguanian-Datangian boundary in South China. Geological Bulletin of China, 23, 742-746.

Tian, S. \& Coen, M. 2005. Conodont evolution and stratotype sign of Carboniferous Tournaisian-Visean boundary in South China. Science in China Series D, Earth Sciences, 48, 2131-2141; doi: 10.1360/04yd0223. 
Tynan, M.C. 1980. Conodont biostratigraphy of the Mississippian Chainman Formation, western Millard County, Utah. Journal of Paleontology, 54, 1282-1309.

Varker, W.J. \& Sevastopulo, G.D. 1985. The Carboniferous System: Part 1 - Conodonts of the Dinantian Subsystem from Great Britain and Ireland. In: A Stratigraphical Index of Conodont (eds. Higgins, A.C. \& Austin, R.L.). The British Micropalaeontological Society, Ellis Horwood Limited, Chichester, 167-209.

Weyant, M. 1985. North Africa conodonts. In: The Carboniferous of the World, Volume II (eds. Wagner, R.H., Winkler Prins, C.F. \& Granados, L.F.). Instituto Geológico y Minero de España, Madrid, 364-367.
Wirth, M. 1967. Zur Gliederung des höheren Paläozoikums (Givet-Namur) im Gebiet des Quinto Real (Westpyrenaen) mit Hilfe von Conodonten. Neues Jahrbuch für Geologie und Paläontologie Abhandlungen, 127, 179-244.

Ziegler, W. 1960. Die Conodonten aus den Gerollen des Zechsteinconglomerate von Rossensay (sudwestlich Rheinberg/Niederrhein). Fortschritte in der Geologie von Rheinland and Westfalen, 6, 1-15.

Ziegler, W. 1962. Taxonomie und Phylogenie Oberdevonischer Conodonten und ihre stratigraphische Bedeutung. Abhandlungen des Hessischen Landesamtes für Bodenforschung, 38, 1-166. 
